\section{MS30-P38 Synthesis and X-ray structural study of two new polymorphs coordination complexes based on imidazol derivative}

Bouacida Sofiane ${ }^{1,2}$, Bouchouit Mehdi², Bouraiou Abdelmalek ${ }^{2}$, Merazig Hocine ${ }^{2}$, Belfaitah $\mathrm{Ali}^{3}$

1. Département sciences de la matière, université Oum El Bouaghi, 04000 Oum El Bouaghi Algeria

2. Unité de Recherche de Chimie de l'Environnement et Moléculaire Structurale, Université Constantine 1. Constantine 25000, Algéria.

3. Equipe de Synthèse de Molécules à Objectif Thérapeutique, Laboratoire des Produits Naturels d'Origine Végétale et de Synthèse Organique. Université Constantine 1. Constantine 25000, Algéria.

email: bouacida_sofiane@yahoo.fr

Polymorphism is very common among pharmaceutical substances. As the polymorphs possess different internal organization within the solid, they often show different melting points, solubilities, chemical reactivity or stability. These can appreciably influence pharmaceutical properties such as dissolution rate and bioavailability. It is therefore important to evaluate the polymorphism in early stages of new formulation studies.

We report here the synthesis, crystallographic study and hydrogen bond interactions of two new polymorph coordination complexes based on imidazol derivative and Cobalt.

Polymorph (I) is triclinic with space group $\mathrm{P}-1$ and cell parameters $\mathrm{a}=7.0882(8) \AA, \mathrm{b}=11.9322(12) \AA, \mathrm{c}=$ $14.1882(15) \AA, \alpha=71.417(5)^{\circ}, \beta=86.927(5)^{\circ}, \gamma=83.489(5)^{\circ}$ $\mathrm{V}=1129.9(2) \AA^{3}$, and $\mathrm{Z}=2$. Polymorph (II) is monoclinic with space group $\mathrm{P} 21 / \mathrm{n}$ and cell parameters $\mathrm{a}=7.5554(2) \AA, \quad \mathrm{b}=13.0466(5) \AA, \quad \mathrm{c}=23.3958(9) \AA$, $\beta=94.405(2),{ }^{\circ} \mathrm{V}=2299.36(14) \AA^{3}$, and $\mathrm{Z}=4$.

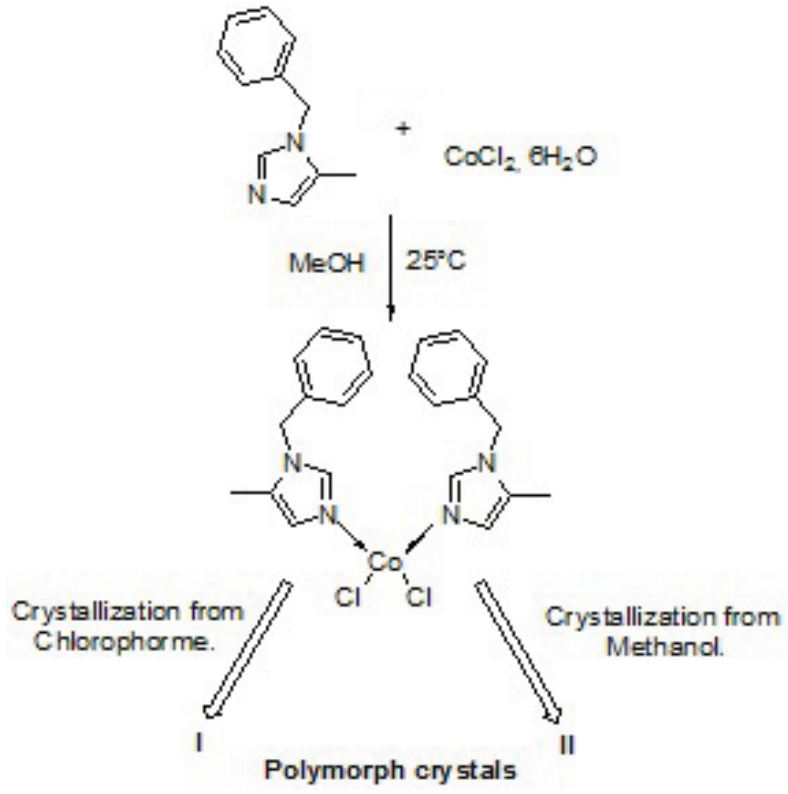

Figure 1. Scheme

Keywords: Polymorphism, single crystal, hydrogen bond, imidazol derivatives
MS30-P39 The role of methanol molecule in supramolecular assembling of $\left[\mathrm{MoO}_{2} \mathrm{~L}\left(\mathrm{CH}_{3} \mathrm{OH}\right)\right] \cdot \mathrm{CH}_{3} \mathrm{OH}$ and
$\left[\mathrm{MoO}_{2} \mathrm{~L}\left(\mathrm{CH}_{3} \mathrm{OH}\right)\right]$ Schiff base type
complexes

Robert Katava ${ }^{1}$, Gordana Pavlović ${ }^{1}$, Marina Cindrić ${ }^{2}$

1. Department of Applied Chemistry, Faculty of Textile Technology, University of Zagreb, Prilaz baruna Filipovića 28a, Zagreb 10000, Croatia

2. Department of Chemistry, Faculty of Science, University of Zagreb, Horvatovac 102a, HR-10000 Zagreb, Croatia

email: robert.katava@ttf.hr

Investigations of Schiff base molybdenum(VI) complexes have been stimulated by discovery of molybdenum in a number of redox enzymes and their efficiency as catalysts both in heterogeneous and homogenous reactions. Reactions of tridentate O,N,O Schiff base ligands $\mathrm{H}_{2} \mathrm{~L}$ with $\left[\mathrm{MoO}_{2}(\mathrm{acac})_{2}\right]$ afforded a series of distorted octahedral cis- $\mathrm{MoO}^{2+}$ complexes of the $\left[\mathrm{MoO}_{2} \mathrm{~L}\left(\mathrm{CH}_{3} \mathrm{OH}\right)\right] \cdot \mathrm{CH}_{3} \mathrm{OH} \quad(\mathbf{1 - 4})$ and $\left[\mathrm{MoO}{ }_{2} \mathrm{~L}\left(\mathrm{CH}_{3}^{2} \mathrm{OH}\right)\right]^{3}(\mathbf{5})$ type. Coordinated $\mathrm{CH}_{3} \mathrm{OH}$ molecule, positioned trans to oxido oxygen atom, could be readily removed from first coordination sphere of molybdenum(VI) cation, yielding a $\left[\mathrm{MoO}_{2}(\mathrm{~L})\right]$ intermediate responsible for catalytic activation of substrates during Lewis acid catalyzed transformations.

The supramolecular architecture of complexes is dominated by two types of hydrogen bonds (HB): $\mathrm{O}-\mathrm{H} \cdots \mathrm{O}$ and $\mathrm{C}-\mathrm{H} \cdots \mathrm{O}$. The supramolecular motif shaped by $\mathrm{O}-\mathrm{H} \cdots \mathrm{O}$ HB in $\mathbf{2 , 3}$ and $\mathbf{4}$ differs in comparison with that formed by the same type of HB in $\mathbf{1}$ and $\mathbf{5}$.

The infinite chains in $\mathbf{2}, \mathbf{3}$ and $\mathbf{4}$ are shaped via the $\mathrm{O}-\mathrm{H} \cdots \mathrm{O} \mathrm{HB}$ which include the coordinated $\mathrm{CH}_{3} \mathrm{OH}$ oxygen atom, $\mathrm{CH}_{3} \mathrm{OH}$ solvent molecule and the oxido oxygen atom of the complex molecule (Fig. 1a). On the contrary, the supramolecular dimers in $\mathbf{1}$ are formed by two molecules of solvent $\mathrm{CH}_{3} \mathrm{OH}$ and two complex molecules via the phenolate oxygen atom and oxygen atom from coordinated $\mathrm{CH}_{3} \mathrm{OH}$ (Fig.1b). Formed dimers are condensed with complex molecules via $\mathrm{C}-\mathrm{H} \cdots \mathrm{O}$ intermolecular hydrogen bond which form centrosymmetric puckered 15-membered ring. (Figure 1b). Complex 5 does not contain solvent molecule of crystallization and the main supramolecular synthon formed via $\mathrm{O}-\mathrm{H} \cdots \mathrm{O}$ hydrogen bond is centrosymmetric dimer between the $-\mathrm{OH}$ group of coordinated methanol and the oxygen donor atom of five-membered chelate ring of another complex molecule (Fig. 1c).

The determination of supramolecular role of $\mathrm{CH}_{3} \mathrm{OHmolecules}$ is essential in the context of complexes solubility and their catalytic activity in the conditions of epoxidation.
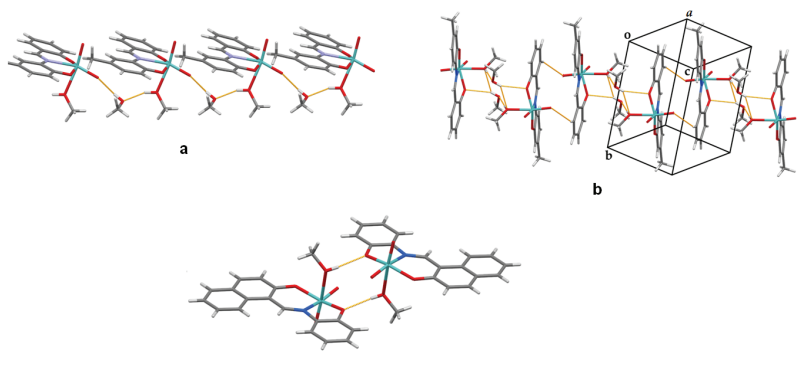